\title{
Higher education and career development experiences of emerging adults: A focus on university students and graduates in Haiti
}

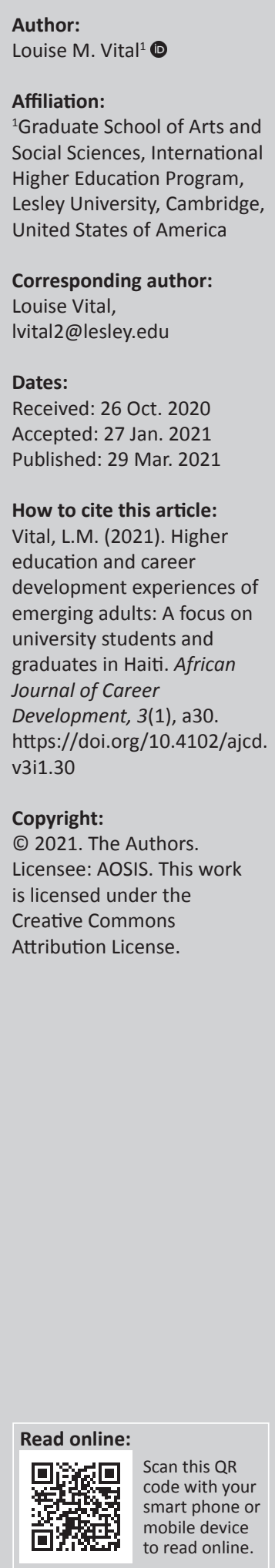

Background: There is limited empirical research on students' experiences in the Haitian higher education system, and even fewer that examined university-based career counselling and the career trajectory of university graduates in Haiti.

Objectives: The purpose of this study was to examine the perceptions of the higher education experiences and career development of university students and graduates in Haiti.

Method: This study emerged from a larger qualitative case study conducted in 2013 on HigherEdOrg (pseudonym) - a higher education-centred organisation in Haiti - whose services for university students and organisation alumni include career counselling. Data collection included semi-structured and focus group interviews, participant observation and document analysis.

Results: Data analysis revealed two overarching themes: challenges to a university-tocareer pipeline in Haiti and multi-pronged career guidance. A combination of countrylevel opportunity constraints and university-specific academic structures contributed to higher education and career challenges for emerging adults in Haiti. Conversely, these university students and graduates affiliated with HigherEdOr, found the comprehensive support provided alleviated those difficulties. Implications include the possibility of a new model of Haitian higher education that integrates career counselling as a new area of focus.

Conclusion: Although emerging adults in Haiti experience considerable challenges in their higher education and career development experiences, the findings revealed a pipeline between higher education attainment and positive career outcomes for those affiliated with HigherEdOrg. Recommendation for future research includes analysis of the career guidance offered to university students in Haiti, which will inform the design of targeted and relevant research projects to address this understudied issue.

Keywords: Haiti; higher education; career counselling; emerging adulthood; non-government organisations; low-income country.

\section{Introduction}

There are positive outcomes associated with educational attainment, with increased schooling resulting in benefits to individuals and society (Akinyemi \& Ofem, 2012; Harper, Patton, \& Wooden, 2009; Kezar, Chambers, \& Burkhardt, 2005; Lewis \& Hearn, 2003). Among the many benefits, individuals are likely to obtain more technical jobs and receive job promotions with the additional education and academic preparation they have received. Not only do the individuals have the potential for a greater income, but they also experience an increase in wages for every year they attend school, apart from gains in critical thinking, skills development, employment readiness and socialisation, and life-long learning, amongst other outcomes (Coates \& Edwards, 2011; Tight, 1989). The benefits of increased education to society are considerable as well. Higher education is important for social equity, mobility and integration (Brennan \& Teichler, 2008), resulting in individual participation that in turn benefits the larger society (Belyakov, Cremonini, Mfusi, \& Rippner, 2009). Lowell and Findlay (2001, p. 1) found that the level and distribution of educational attainment has a strong impact on social outcomes, such as child mortality, fertility, education of children and income distribution' (p. 1). Earning a higher education degree leads to income growth, expanded range of choices and increased relevant skills (Ozsoy, 2008). Furthermore, obtaining higher levels of education leads to better living conditions, better jobs and 
social development (UNESCO, 2009, 2014). Education, therefore, can be viewed as 'a leveller reducing societal inequalities and enabling larger numbers of a population to share in the growth process' (Carlson et al., 2011, p. 10). Given the benefits of higher education and the employment outcomes for those who have earned higher education degrees, it stands to reason that students who attend university have an expected positive career outcome after graduation.

Students choose to pursue higher education for a number of reasons: opportunities for financial security, a good quality of life and life-long learning are a few to mention (ChamorroPremuzic \& Frankiewicz, 2019). Depending on the country context, those enrolled in higher education institutions receive career training and are prepared to work in professional settings and perform in entrepreneurial, managerial and technical positions, amongst others (Birdsall, 1996; Maree, 2009; Iakovleva, Kolvereid \& Stephan, 2011). Overall, it is expected that higher education meets the needs of three categories of stakeholders: students who want access to higher education, employers who expect graduates who are appropriately skilled for the market and countries that want to stimulate development by the presence of institutions of higher education (Somers et al., 2006). Despite what is known about the benefits of earning a higher education degree, and the connection between an earned university degree and positive career outcomes to both the individual and local society (Hoyt \& Allred, 2008), career counselling is not a major function of the university experience for undergraduate students in Haiti.

The purpose of this study was to examine the higher education experiences and career training of university students and graduates in Haiti. This study is drawn from a larger case study conducted of HigherEdOrg (pseudonym), a higher education-centred non-governmental organisation (NGO) responding to university access and persistence in Haiti (Vital, 2015). Amongst the range of services provided, HigherEdOrg offers comprehensive career services to university students and alumni affiliated with the programme, which is the focus of this study. This research was warranted because as Brennan and Naidoo (2008, p. 293) summarised, 'participation in higher education is important because of its implications for an individual's life chances in the long term'. Approximately 21090 individuals receive vocational training in Haiti (Suzuta, 2011), and there is some scholarship and practice-based reporting on the efficacy of such training (Bigelow, 2010; RTI International, 2018). There is limited empirical research on student experiences in the Haitian higher education system (Vital, 2015; Dumay, 2009; Endicott, 2019; Jacob, 2020; Pierre, Arrellano, Ramírez, Gómez, \& Romero, 2014; Rameau, Louime, \& BeharHorenstein, 2007; Zanotti, Stephenson, \& McGehee, 2016) and even less that specifically examined the university-based career training preparation programmes and trajectory of university students and graduates in Haiti. This research addressed a gap in research on career counselling in the
Haitian context. More specifically, it advances the scant empirical research that exists, and discusses the connections between Haitian higher education and career counselling.

The researcher's visit to Haiti provided an opportunity to interview both students and alumni of HigherEdOrg, who were also students and graduates of the Haitian university system at the time of this research. Together, this group of HigherEdOrg participants were able to highlight the career counselling they were receiving at the time of the research and speak about the outcomes of the career counselling received as current university graduates working in the local job market. As the terms 'emerging adults' and 'emerging adulthood' describe the human development that occurs between the ages of 18 and 25 (Arnett, 2000), these terms will be used interchangeably with 'university students and graduates' to reflect on the participants of this study who discussed their experiences as career-seeking university students and university graduates in Haiti within this age range. Interviews with the HigherEdOrg staff members that provided career preparation and counselling along with external stakeholders from the Haitian Ministry of Education and a local research institute offered a necessary contextual background to the career counselling and prospects of emerging adults in Haiti. Learning of the higher education and career preparation experiences of university students and graduates in Haiti provides a lens for understanding the complex realities they face as emerging adults, as they seek to enter the local job sector. Furthermore, examining the services and interventions provided by HigherEdOrg staff members to mitigate those complex realities allows for a holistic understanding of the career development experiences of university students and graduates in Haiti. Thus, the question guiding this work was the following: what are the higher education and career development experiences of emerging adults in Haiti?

\section{Emerging adulthood and career counselling in low-income countries}

In his seminal work, Arnett (2000) focused on the ages of 18-25 years as a new concept of development that he referred to as emerging adulthood. According to Arnett (2000, p. 469), emerging adulthood is distinguished by 'relative independence from social roles and normative expectations' and emerging adults' emphasis on becoming self-sufficient as a marker of transition to adulthood (Arnett, 1998). He further explained that during this time, 'young people obtain the level of education and training that will provide the foundation for their incomes and occupational achievements for the remainder of their lives' (Arnett, 2000, p. 469). Although his work in 2000 introduced a theory that offered new insight into human development, the framework Arnett offered was limiting as it emphasised the period of emerging adulthood in the context of industrialised societies, including the United States of America. The work of Juarez and Gayet (2014) advanced the understanding of adulthood, specifically the transition to adulthood in the context of developing countries such as Haiti. 
Juarez and Gayet (2014) described transition to adulthood from the economic, social and cultural contexts of Africa, Asia, Latin America and the Caribbean. Focusing on the transition to adulthood in these contexts allows individuals to consider how 'economic and social inequality, institutions, and families of origin have determined the course of young people's transitions to adulthood' (Juarez \& Gayet, 2014, p. 522). Given the increasing interconnectedness of the world community, Juarez and Gayet (2014, p. 522) explained that the transition to adulthood has changed over time and that country or regional specific norms, standards and expectations are influenced by a 'globalized world that encourages new lifestyles beyond borders'. In their work on workforce development, Tan, Lee, Valerio and Nam (2013) also noted the influence of globalisation, along with technology, on the demand for skilled workers. The coronavirus disease 2019 (COVID-19) pandemic has heightened awareness of the precariousness of those living in low-income and emerging economies. The pandemic has implications for decent work and economic growth, with 1.6 billion workers in the informal economy at risk of losing their livelihoods (UN, 2015). Understanding the factors that shape the lived experiences of emerging adults in developing countries is helpful when seeking to understand their higher education and career preparation experiences, and later, as they seek to enter the local job sector.

Job training, preparation, education or development can occur in various formats. Broadly, career counselling is provided to individuals 'to make educational, training and occupational choices and to manage their careers' and the services available may be offered 'in schools, in universities and colleges, in public employment services, in companies, and in the voluntary and private sectors' (Watts \& Fretwell, 2004, p. 2). In their report on the job-relevant skills required to enter the workforce in developing and emerging economies, Tan et al. (2013, p. iii) noted the 'mismatch in skills demand and supply' in those contexts (p. iii). In lowincome countries, most workforce development occurs through informal or private, formal technical and vocational education and training schemes (Janjua \& Naveed, 2009; King \& Palmer, 2010). In this context, local governments often do not have the capacity to offer comprehensive, well-resourced technical and vocational education and training. Furthermore, the development of career guidance programmes may be at lower priority as choice in occupation and preference for specific careers are not as readily available.

Counselling services programmes may have various components, including individual or group training that is in-person or online, specific career information and advice, opportunities for self-assessment, job preparation including interviews and print work, and the facilitation of apprenticeships or internships (Watts \& Fretwell, 2004). There is evidence of career counselling in higher education contexts (Bittaye, Odukogbe, Nyan, Jallow, \& Omigbodun,
2012; Maree, 2009; Sidiropoulou-Dimakakou, Argyropoulou, Drosos, Kaliris, \& Mikedaki, 2016; Sun \& Yuen, 2012). Maree (2009) explored career counselling offered in South African institutions of higher education. In his work Maree asserted that every student at every higher education institution should have access to career counsellors who are trained to assess, counsel and mediate career-related questions. Bittaye et al.'s (2012) research on career counselling for medical students in Gambia found that the opportunity for mentorship by senior colleagues was a significant factor for male medical students entering particular medical specialties. However, all the students reflected in their study indicated that there was no career counselling offered by the medical school, which the researchers indicated had implications on students' choice of their intended medical specialties (Bittaye et al., 2012). Research on the experiences of Greek university students noted that opportunities to gain and practise skills relevant to all work fields and particular occupations, experiential activities, seminar-type workshops and interventions that focused on students' perceived selfefficacy beliefs in their career and career adaptability were effective strategies of career counselling in higher education (Sidiropoulou-Dimakakou et al., 2016, p. 47). Sun and Yuen (2012) concluded that career guidance and counselling for university students in China should not copy approaches from foreign countries and instead:

Chinese theories and strategies for career guidance and counselling should be created, with due reference to Chinese society's characteristics, practical problems ... job market, employment system, educational philosophy and the social value system. (p. 207)

Taken, all together, emerging adults in developing countries often experience economic and social inequality, and less than favourable job options. Yet, comprehensive career guidance and counselling that is coupled with higher education attainment may lead towards positive career preparation and more optimal outcomes.

This brief review of emerging adulthood and career counselling in low-income countries was offered to highlight the uniqueness of career counselling in the higher education environment in Haiti. Higher education does not always lead to employment, or employment that aligns with skills and academic training, and this is true for Haiti. In a global context, it is understood that there is a positive connection between higher education graduation and career attainment, broadly. However, although data collection for this study occurred in 2013, there does not seem to exist any empirical research that describes a university-to-career pipeline in Haiti. More specifically, career counselling and the patterns for people who attend and graduate from university are understudied in the Haitian context. This scholarly work is focused on the higher education and career development experiences of emerging adults in Haiti. The following section offers a contextual background of Haiti, including the higher education and career experiences of university students in Haiti. 


\section{Contextual background: Higher education and career experiences in Haiti}

Haiti's history is marked by periods of political and economic instability and catastrophic natural disasters, including its devastating 2010 earthquake and Hurricane Matthew in 2016, described as the 'fiercest Caribbean storm in nearly a decade' (Brice \& Marsh, 2016). Given its complicated history and contemporary realities, Haiti is noted as the poorest and least developed country in the Western Hemisphere (Ferguson, Desir, \& Bornstein, 2014), and it ranks 214 out of 217 countries in terms of unemployment rates (CIA, 2019). In 2020, the unemployment rate in Haiti was $16.74 \%$ for women and $11.37 \%$ for men (The World Bank, 2020). In 2010, the labour force by occupation was $38.1 \%$ agriculture (farming, fishing and forestry), $11.5 \%$ industry (mining, manufacturing, energy production and construction) and 50.4\% services (government activities, communications, transportation, finance and all other economic activities that do not produce material goods) (CIA, 2019; Index Mundi, 2019). Haiti's economic position has implications for the higher education and career prospects of the emerging adults in the country. In 2019, Haiti had a population of over 11.2 million individuals.

Given the challenging educational realities in Haiti, the United States Agency for International Development (USAID, 2017) indicated that there is a generation of Haitian youth who are at risk of lacking the knowledge and basic skills necessary to succeed in the labour force. Less than $1 \%$ of the Haitian population attends a university in Haiti (Dumay, 2010). Of the less than $1 \%$ of those who study in Haiti, only $50 \%$ of those students eventually earn a university degree, and $84 \%$ of university graduates leave Haiti after graduation (Jadotte, 2012; Ratha \& Shaw, 2007). This phenomenon is known as brain drain; in 2012 Haiti had a high rate of brain drain, which included more skilled people leaving the country as compared to other countries in the Caribbean region (Clinton, 2012; Jadotte, 2012). The majority of graduates leave Haiti for job prospects in other countries, mainly in the USA, Canada and other parts of the Caribbean (Joseph, 2011). Included in their reasons for departure is the lack of capacity in the local job market, and a mismatch between their disciplinary training and the positions available in Haiti. This has resulted in a brain drain within the country (Vital, 2015, 2017; Lemay-Hébert, Marcelin, Pallage, \& Cela, 2020).

\section{HigherEdOrg}

HigherEdOrg is a higher education-centred NGO located in Port-au-Prince, Haiti. The organisation envisions all Haitians having access to quality education and the ability to contribute to local society. It is an independent organisation and is not a function of the Ministry of Education, or any institution of higher education in Haiti. HigherEdOrg has staff located in Haiti and New York, the United States of America. The Haiti-based staff members work directly with the programme participants. The staff members in Haiti strive to create and maintain relationships with local universities and the Ministry of Education. They also attempt to develop connections with companies in Haiti and academic programmes outside of Haiti for the purposes of generating internships and educational enrichment opportunities for its students. The staff members in New York primarily work on development and fundraising for the organisation.

The NGO was founded in 1997 and its aim is to provide scholarships to talented young Haitians who do not have the financial means to access higher education studies. HigherEdOrg values gender development and sustainable practices. It operationalises these values by reserving $40 \%$ of the seats for women in each new class, and by having a staff that is comprised by a majority of women, who are also represented in leadership positions. Initially it was supporting one university student, and presently supports approximately 130 students a year who are in various levels of study (first through fifth year). In addition, HigherEdOrg has more than 30 alumni who have access to the career-related services and resources of the organisation. For the purposes of the scholarships it provides, HigherEdOrg recruits high achieving students demonstrating the most financial need. Once admitted, HigherEdOrg students must attend universities recognised by the Ministère de l'Education Nationale d'Haïti [Ministry of Education] and the Association of Francophone Universities and must maintain a 3.0 grade point average.

The HigherEdOrg scholarship provided to its scholars is comprehensive. Acceptance into the programme includes full university tuition, textbooks and supplies, access to a computer lab with Internet access, an onsite library, academic advising and study abroad opportunities in the United States of America. HigherEdOrg scholars also attend three organisation-designed enrichment courses: 2 years in computer literacy, 4 years of English as the second language and 4 years of leadership courses that have a social justice orientation. Students are also required to participate in extracurricular activities that include a speaker series, field trips and retreats. HigherEdOrg also offers students counselling support. The scholarship also provides housing in a HigherEdOrg residence and a monthly living stipend. Students in their final year at university are assigned a thesis advisor and receive national exam preparation support. HigherEdOrg students and alumni receive career guidance, including workshops with guest industry and alumni guest speakers, cover letter and curriculum vitae reviews for future professional and academic opportunities domestically and abroad, and internship opportunities with local and international organisations, which is managed by the Career and Alumni Services Manager.

Table 1 presents HigherEdOrg statistics as they relate to overall country statistics in key areas.

TABLE 1: HigherEdOrg statistics.

\begin{tabular}{lcc}
\hline How HigherEdOrg is changing the stats & Haiti & HigherEdOrg \\
\hline Students on Dean's list (\%) & 8 & 40 \\
University graduation rate (at the time of the study) (\%) & 40 & 80 \\
University graduates working in the country (\%) & 16 & 80 \\
Employment rate (\%) & 50 & 90 \\
Average annual salary (\$) & 820 & 14900 \\
\hline
\end{tabular}

Source: Adapted from Haitian Education and Leadership Program (HELP), (n.d.). How HELP is changing the stats. Retrieved from https://uhelp.net/our-story/results/ 


\section{Conceptual framework}

This study is framed by the work of Holman (2014) who developed a report on good career guidance based on his visit to and analysis of six countries viewed as having positive career guidance and educational results (Canada, Finland, Germany, Hong Kong, Ireland and the Netherlands) and five independent schools in England. The key components of the eight-part good career guidance benchmarks are the following: (1) a stable career programme, (2) learning from career and labour market information, (3) addressing the needs of each pupil, (4) linking curriculum learning to careers, (5) encounters with employers and employees, (6) experiences of workplaces, (7) encounters with further and higher education and (8) personal guidance. The eight benchmarks for providing good career guidance to pupils in schools are adaptable to the work of HigherEdOrg. The organisation functions in a manner similar to that of higher education institutions as it responds to the academic, social, financial and emotional needs of the scholars associated with its programme.

Holman (2014) provided descriptions for each benchmark. A stable career program: 'Every school and college should have an embedded programme of career education and guidance that is known and understood by pupils ... and employers'. Learning from career and labour market (Holman, 2014):

Every pupil should have access to good quality information about future study options and labour market opportunities. They will need the support of an informed adviser to make best use of available information. (p. 7)

Addressing the needs of each pupil: 'Pupils have different career guidance needs, at different stages. Opportunities for advice and support need to be tailored to the needs of each pupil'. Linking curriculum learning to careers: 'All teachers should link curriculum learning with careers'. Encounters with employers and employees (Holman, 2014):

Every pupil should have multiple opportunities to learn from employers about work, employment and the skills that are valued in the workplace. This can be through a range of enrichment activities including visiting speakers, mentoring and enterprise schemes. (p. 7)

Experiences of workplaces: 'Every pupil should have first-hand experiences of the workplace through work visits, work shadowing and/or work experience to help their exploration of career opportunities and expand their networks'. Encounters with further and higher education (Holman, 2014):

All pupils should understand the full range of learning opportunities that are available to them. This includes both academic and vocational routes and learning in schools, colleges, universities and in the workplace. (p. 7)

Personal guidance: 'Every pupil should have the opportunities for guidance interviews with a career adviser, who could be internal or external, provided they are trained to an appropriate level' (p. 6). These benchmarks offer a useful framework for examining the range of academic and career supports HigherEdOrg provides to university students in Haiti.

At first glance, it may seem counter-intuitive to frame this study on a conceptual framework based on country contexts vastly different from Haiti and its low-income country status. However, Holman's (2014) Good Career Guidance offers a framework that illuminates the approach of HigherEdOrg, an organisation that incorporates both Haiti-based and international perspectives in its work with university students in the country. HigherEdOrg is an innovative presence in the higher education landscape in Haiti. The career development approach of the Career and Alumni Services unit includes a combination of training and guidance that provides a foundation for HigherEdOrg students and alumni to draw from as they prepare to engage in the local job sector.

\section{Methods}

This was a qualitative case study of a higher educationcentred organisation in Haiti, HigherEdOrg (pseudonym). Stake (2005) emphasised that an NGO may be a case and HigherEdOrg identifies as such in Haiti. The case study provided a detailed description of the organisation and the strategies it utilised to respond to the challenges that university students experience within the Haitian higher education system and post-graduation. The question guiding this research was as follows: what are the higher education and career development experiences of emerging adults in Haiti? Findings provided insight into how HigherEdOrg students conceptualised their university experiences in Haiti and the implications to their future careers, the range of support provided by HigherEdOrg related to career development, and the local career prospects for HigherEdOrg alumni after university graduation. In this sense, participants both 'described an intervention and the real-life context in which it occurred' (Yin, 2003, p. 15), which was useful for the data analysis for this study.

\section{Participants}

The case study of HigherEdOrg was conducted in Portau-Prince, the capital of Haiti. With regard to participant recruitment, after this study was conceptualised, the New York-based founder and executive director of HigherEdOrg was contacted to learn if the organisation could serve as the site and focus of the research. After receiving approval, participant recruitment material written in French was sent to the Haiti-based Associate Director of HigherEdOrg to forward onto organisation students, alumni and staff. The email included information about the study, participant requirements and my expected arrival and duration in Haiti. Potential participants were given the option of prescheduling their interview or confirming an appointment with me after I arrived in Haiti. Snowball sampling (Patton, 2002) was also utilised to recruit participants after I arrived in the country. 
The participants reflected in this study on higher education experiences and career development in Haiti included HigherEdOrg students (1), HigherEdOrg alumni (2) and HigherEdOrg staff (7). In an attempt to gain a holistic understanding of career preparation and counselling approaches in Haiti, interviews with HigherEdOrg staff (one of whom was also a programme alumni), an administrator from the Haitian Ministry of Education and the Associate Director for the Interuniversity Institute for Research and Development (INURED) provided the contextual background to the higher education experiences and career development of emerging adults in Haiti. According to its website, INURED's (n.d.) mission is to 'contribute to the development of high-level research and scientific training in Haiti with the aim of improving the educational, socio-economic and political condition of Haiti's people' (Para 1.). Participants either selected a pseudonym or asked that one was to be assigned to them. In total, 11 participants were interviewed. Given the range of backgrounds and experiences of the participants interviewed, I was able to collect rich data that increased the trustworthiness of the interviews analysed (Glesne, 2011), which offered insights into the higher education and career development experiences of emerging adults in Haiti and those who address these concerns in the country.

\section{Data collection and analysis}

This study emerged from a larger qualitative case study conducted in 2013 on HigherEdOrg that focused on university access and persistence in the Haitian higher education system. Additional analysis of the data collected revealed findings related to higher education experiences and career counselling that together reflected the career development experienced by university students and graduates affiliated with HigherEdOrg themes specific to this study. I utilised a multi-method approach, including semi-structured and focus group interviews, observation and document analysis to collect the data. All interviews occurred face-to-face with participants and lasted for between $15 \mathrm{~min}$ and $60 \mathrm{~min}$. Semi-structured interviews of HigherEdOrg stakeholders (students, alumni and staff) and focus group interviews of teaching staff occurred in various locations, including one in the student residences located in the capital provided by the organisation, in their staff offices and in the courtyard of the HigherEdOrg centre. Semistructured interviews of the INURED AD occurred at the INURED office building and the interview with the Ministry of Education administrator occurred at a café in the capital. Reflexive memos (Glesne, 2011) were written after each interview for me to capture my initial reactions and learnings from each interview. Interviews were conducted in Haitian Creole, French and English. Non-English interview data were translated and transcribed after I returned to the USA. I completed the first round of the Haitian Creole translation to English. A native Haitian Creole and French speaker confirmed the accuracy of the Haitian Creole translation and made necessary corrections, and also conducted the translation of data from French to English. The translator confirmed that idioms and culture-specific terminologies were accurately translated and described in the transcription, and were understood by me, the researcher. The transcribed interview data went through first and second cycle coding, following a scheme outlined by Miles, Huberman and Saldaña (2014). After in-depth analysis of the interview data, findings related to this study emerged.

Observation was another method of data collection. I resided in a HigherEdOrg student residence during my month-long research visit in Haiti. I observed student interactions, study habits and engagement with student staff, and we had informal discussions regarding their HigherEdOrg experiences. I also observed the dynamics at the HigherEdOrg centre, including those between students, students and staff, staff and staff, staff with external visitors, staff meetings, student and staff meetings and the annual student graduation. The data collected from my observation allowed me to 'use my senses, especially looking and listening in a systematic and meaningful way' (McKechnie, 2008, p. 573), which deepened my examination of HigherEdOrg.

My final data collection method was document review. In total, I reviewed 110 pages of the organisation's documents, including its organisational chart, student handbook, monthly reports, information management system guide, student profiles, summary of student needs, advisory guide, and applications for admission and academic scholarship forms. The organisation's website was also a source of relevant data. Analysing the organisation's documents provided background information and meaning to the interviews I conducted and dynamics that I observed (Glesne, 2011), which provided a holistic understanding of HigherEdOrg. Overall, the qualitative case study approach allowed me to 'close in on real-life situations' (Flyvbjerg, 2006 , p. 235) and helped me to understand the problem under study.

\section{Trustworthiness and validity}

I used several methods of testing to rule out validity threat. The first test included respondent validation and member checking. Respondent validations included 'systematically soliciting feedback about your data and conclusions from the people you are studying' (Maxwell, 2005, p. 111). This member-checking process occurred throughout my inquiry and via the 'data I played back to the informant to check for perceived accuracy and reactions' (Cho \& Trent, 2006, p. 322). These processes helped me to ensure that what I understood I learned from the interviews was in fact what the participant intended to convey. Their feedback confirmed my internal conclusions and that I was not misinterpreting what I gleaned from previous interviews. This was particularly important as the interviews were conducted in multiple languages: English, French and Kreyòl Ayisyen [Haitian Creole]. The second validity test was triangulation, which, in qualitative case studies, 'is a common means through which researchers increase the trustworthiness of their representation of the case' (Grandy, 2010, p. 1). The larger study utilised multiple data sources (34 participants), 
data collection methods (semi-structured interviews, focus groups, observation and document review) and my field notes. The data collected revealed consensus between participants, the documents analysed and the observations concluded. Lastly, I consulted with a peer who is familiar with conducting qualitative case studies. This peer review process (Glesne, 2011) included discussing my data collection methods, coding scheme and themes that emerged. This feedback loop provided outside and objective suggestions that allowed me to refine my findings and strengthen my conclusions.

\section{Researcher reflexivity}

As I conceptualised my study research in Haiti, it was important that I reflect on any bias I would bring to this research project (Maxwell, 2005). My mother and father were born and raised in Haiti. I am a first-generation American and grew up in a close-knit Haitian community in the United States of America. I am also a heritage speaker of Haitian Creole. Given how strongly I felt connected to my ethnic heritage, it was critical that I examined how my positionality might influence my research process; I was aware of the potential bias I would bring and recognised the lens from which I would be conducting and analysing my Haiti-based study. Prior to the start of my research project in Haiti, I reflected on the fact that I was a scholar who was born, raised and academically trained in the United States of America. I was concerned about being labelled an 'other' or viewed as an 'outsider' by Haitians in Haiti. I was anxious about revealing a subconscious bias that favoured my American self over my Haitian self. Smith $(1999$, p. 66) states that the 'western culture constantly reaffirms the west's view of itself as the centre of legitimate knowledge'. To combat any preconceptions that I may have brought to my work in Haiti, I attempted to bracket the deficit narratives that I was inundated with throughout my life that overwhelmingly described Haiti and Haitian education from a negative viewpoint, and instead focus on the first-hand knowledge of educational experiences in Haiti from the study participants. Through my reflexive memos I continually checked myself on how I was thinking about education in Haiti by listening to my participants, instead of introducing what I learned prior to my study of the interviews. I wanted to ensure that I was viewing participant responses and experiences as authentic and valid. I strived to make sense of what I was learning from their Haitian perspective, and to limit as much as possible, juxtaposing my American perspective in meaning making and interpretation of the data collected (Creswell, 2009).

\section{Ethical considerations}

This study was approved by and granted exempt status from the Michigan State University Institutional Review Board (IRB\# x13-485e Category: Exempt 1.2) and informed consent was obtained from all the participants. The case study was conducted on an entity outside of any formal Ministry of Education or higher education institution purview. As such, a Haiti-based IRB application was not submitted or requested. However, an explanation of the study was submitted to
HigherEdOrg and permission to conduct the study was obtained from the organisation's executive director.

\section{Results}

Analysis of the data from the larger case study revealed findings related to perceptions of higher education training and career prospects for university students and graduates in Haiti, and the related implications on their career development and expectations. Findings are organised by two overarching themes: challenges to a university-to-career pipeline in Haiti and multi-pronged career guidance. Together, these themes highlight the necessity of addressing the combination of experiences of emerging adults in Haiti as they relate to their higher education attainment, career development and employment opportunities in Haiti.

\section{Challenges to a university-to-career pipeline in Haiti}

The case study participants discussed a range of higher education and career prospect challenges experienced by university students and graduates in Haiti. The challenges conveyed are categorised by the larger Haiti country context, university-specific experiences, and what participants believed to be nepotism and neo-colonial practices embedded in the higher education and career structures in Haiti. Collectively, these challenges describe a broken universityto-career pipeline experienced by emerging adults in Haiti.

When discussing the experiences of university students in Haiti, Olivia Jean reconceptualised the notion of brain drain broadly as a general lack of opportunity, and explained:

'For me, brain drain is not just for people who leave the country only. I think that when a person is in a place that he can't develop, even if he is in the country, but he doesn't, his heart wants ... he doesn't find the opportunity, or he is doing something else that he does not want to do, he is just doing it because, he makes a way but his brain is not utilized, that means that he is not being utilized the way that he should, that is also a problem.' (Olivia Jean, student, HigherEdOrg)

The lack of a financial aid system creates barriers to university access for students, impeding their opportunities for higher education attainment. The Ministry of Education administrator noted the financial challenges that were barriers for students wanting to pursue higher education in Haiti:

'There is a lot of effort for students to get scholarships in the
country. That means that right now in the country, there is a lot
of demand. At the same time, the State University in the country
of Haiti almost cannot respond to the demand of all of the
students who want to enter the university. Thus, this provides
an opportunity for the private sector to [answer] the question of
higher education not being good here in the country of Haiti.'
(Paul Simon, administrator, Ministry of Education)

From the perspective of staff members working at HigherEdOrg, Margreth Mathieu discussed the complexities 
surrounding pursuing a university degree in Haiti and described the following challenge:

'Entering a university is not just entering a university. Even if he is a State University student, coming from province [the countryside], if he does not have a stable location to stay, stable like he knows in the morning that he will enter a place, it will not be easy for him. Therefore, it is extremely difficult for a student to enter a university right now. To enter is one, to remain entered is another, and there is ... every year this number is rising.' (Margreth Mathieu, student recruiter/alumnus, HigherEdOrg)

For those students who find an opportunity to enter a university in Haiti, they experience challenges to their persistence. Many of the participants described various university academic structures that made it difficult for students to graduate. They conveyed that although students were motivated in their disciplinary areas of study, they often felt discouraged because the academic experience disrupted their matriculation and hopes for degree attainment, and consequently their future employment. Farah Paul provided a nuanced account of the teaching offered at the university level in Haiti and its implications for potential employers:

'It's a major issue because you teach the person how to read and write. You teach them how to make subtractions and multiplications and stuff and then what? How is that person going to become the professional that he is? ... Universities, there's not a lot of them with good quality ... how do you assess the work that they are doing? Same textbooks that [had] been used 20 years ago are the same ones that are being used this year. The people who are teaching at the university they are not ... they're just people who have time to teach. Most of them are not educators. They are just people in the field. They have an extra hour or couple of hours extra. They come in they give a class they go away. This is not really a lot of emphasis on the educational part of it. And the quality. I think that's what worries the potential employers. The quality of the education. It is very obvious that they are looking for that also. And they want their candidate, whoever it is applying for job, they want them to be able to write a letter in English or to write in French. Good French. Since French is the second language that we speak. So, you have expectations but how are you going to ensure the delivery of that? I don't think universities do that. They don't do it. I'm not going to say I don't think. They don't.' (Farah Paul, career and alumni services manager, HigherEdOrg)

An additional academic-related challenge described by participants was the university thesis requirement. Once students addressed barriers to access and navigated various challenges to their university persistence, they were faced with a thesis requirement that must be completed prior to being awarded their baccalaureate degree. The INURED Associate Director discussed this further:

'Although all students are required to complete this component of their baccalaureate degree, based on participant responses, it appeared that there were not enough faculty members to guide students to do so. So, the students are going into the systems and they are not finishing and most of them are not finishing them not because they are not passing their classes. Most of them are not finishing because they can't pass their thesis...' (name not disclosed, associate director, INURED)
Other participants explained that often students arrive to the thesis component of their post-secondary experiences without ever having enrolled in a research course, being taught about how to conduct a research or analyse data, and not understanding how to develop a line of inquiry, let alone conduct a review of the literature. The thesis requirement was seen as a barrier because of the lack of training and preparation to develop a thesis and because a clear indication of how the thesis requirement related to their career aspirations had not been articulated by the faculty.

An additional challenge described by participants included ones that they believed university students had no control over, which contributed to their sense of defeat. HigherEdOrg students, alumni and staff discussed the discouraging reality that the Haitian university degree was not seen as valuable in Haitian contexts. Furthermore, they explained that local entities and even Haiti-based international organisations seemed to value degrees earned outside of the country. Participants noted that any foreign academic experience, even if it was short term, provided an edge for the university graduate on the local job market. Olivia Jean captured this sentiment:

'The first thing that I can say, because like I said before, our education does not have international value. We could get some recognition if there is a school that is affiliated with a school outside. That can give us an opportunity to continue with school. But for us to have an international value, that means more than just getting an education. If we are in Haiti only, you will always have in mind if you want a professional, international ... do your master's another place, you will not want to do your master's here. If you have an opportunity, a person on your side, you go.' (Olivia Jean, student, HigherEdOrg)

The final challenge discussed by participants was broadly perceived to be corruption embedded in the employment sector in Haiti. This was discussed by nearly every HigherEdOrg participant. Guy Andrew, the English as a Second Language (ESL) and Leadership Instructor for HigherEdOrg, highlighted that 'there's a huge, huge amount of nepotism in Haiti. And a lot of people get jobs just through family and a lot of people, they are not qualified for.' Conversely, HigherEdOrg Associate Director described the neo-colonial practices that kept Haitian nationals out of the job sector all together. The Associate Director underscored:

'It's like, how bizarre, how that in Haiti, this extremely impoverished country, how, with an unemployment rate of like $90 \%$, is importing middle management and at the same time, we are exporting the educated Haitian, like that's just stupid. It just doesn't make any sense.' (name not disclosed, associate director, HigherEdOrg)

Emerging adults in Haiti experience considerable challenges to both their higher education experiences and career expectations. Because of country-level opportunity constraints and university-specific academic structures participants explained that post-secondary students face barriers to their access and persistence in university in the 
country. Furthermore, university graduates must contend with what has been perceived to be a corruptive employment environment, which has implications for their career trajectory in Haiti.

\section{Multi-pronged career guidance}

As noted previously, this study is framed by Holman (2014), whose work highlighted eight key benchmarks of a good career guidance programme. The benchmarks are as follows: (1) a stable career programme, (2) learning from career and labour market information, (3) addressing the needs of each pupil, (4) linking curriculum learning to careers, (5) encounters with employers and employees, (6) experiences of workplaces, (7) encounters with further and higher education and (8) personal guidance. The findings of this study reveal that these benchmarks are embedded in the multi-pronged career guidance offered by HigherEdOrg. The range of services that the organisation provides that fosters the career development of its students and alumni are discussed below.

HigherEdOrg Career and Alumni Services Manager Farah Paul provided an in-depth understanding of services provided to current students and alumni of the programme. During her interview she discussed the overall career services she provided, the workshops offered and the support provided for post-graduation. When discussing the intent of the Career Services programme, she explained:

'Our first focus is to place the students. I want them to have this professional experience. It doesn't matter if it's Haitian field, a Haitian organization, or a foreign organization. I really look for the opportunities that can provide them with you know with an internship in their own field. So, this year we've made a lot of progress regarding this specific aspect placing the student in the field that is of interest to him.' (Farah Paul, career and alumni services manager, HigherEdOrg)

In her discussion, Farah explained that offering a stage or internship experience was novel in Haiti. Additionally, some of the students were able to participate in opportunities for international engagement at various institutions in the United States of America. Most university students did not have such opportunities as a component of their university experiences. HigherEdOrg students stood out amongst university students because of the internship experience, and she found that the organisations often sought out programme alumni because of the career preparation they received. Farah also provided insights into the career workshops she offered to programme students and alumni. She noted:

'A lot of them [alumni] see it as "oh I'm done, and I just deposit my CV." But they haven't called me, but they don't know it's a continuous process, and it's a project. And so, actually letting them know how it works really, and then the reality, and how it can work for them is what I've been doing in the past 3 years.' (Farah Paul, career and alumni services manager, HigherEdOrg)
When discussing the alumni support component of her role, Farah explained that older alumni were not aware of her position and that she was available to provide them with support long after they graduated. Although it took some time for her to reach the alumni, she explained that at that point she had developed a good network of programme graduates. The alumni had begun to seek her out for support in their post-graduate endeavours, sometimes for new professional positions or for additional academic pursuits.

Farah alluded to the challenges of the local job market in Haiti. She described:

' $[A]$ nd if there are job opportunities as well, because some of them, all of them are placed, but maybe they are not well placed, maybe there are better opportunities, then I communicate that with them.' (Farah Paul, career and alumni services manager, HigherEdOrg)

Farah highlighted an issue that many of the case study participants discussed - namely, despite earning university degrees and having access to the comprehensive range of services provided by HigherEdOrg, programme alumni must still contend with the job market realities in Haiti, which some described as dire and incompatible with the degrees they earned.

The three required enrichment courses were also discussed by HigherEdOrg participants. When prompted, the alumni explained that the enrichment courses were not in existence when they were students of the programme. Most programme students welcomed the enrichment courses as a function of their scholarship because they believed the courses prepared them for future employment and potential academic opportunities in other countries, including the United States of America and Canada. However, some of the programme students found the course load overwhelming given the full academic load they were concurrently engaged in at their respective universities. Course staff members discussed the aim of the courses and why they believed they were necessary. Each of the course managers shared their insights.

HigherEdOrg Computer Science Assistant Manager Viola Persine explained that unlike experiences in the United States of America, many of the students were engaging in basic computer skills for the first time after becoming programme scholars. She described the support her unit provided:

'I help the students troubleshoot. We do with them like, what is a computer, what is in a computer. This is something that you start small so that they can have abilities with it. There are some who do not know how to send an email. We show them how to do an excel document, create a formula ... then we show them access ... how to save a file.' (Viola Persine, computer science assistant manager, HigherEdOrg)

Program scholars also participated in the leadership course. Embedded in the leadership course is a social justice ideal that speaks about HigherEdOrg's mission to create a more just society. HigherEdOrg Leadership Programme Manager Marie Belizaire discussed the benefits of the course further: 
'I really do think that the transformation is happening, and the students feel really empowered, really good, and have the tools and skills and knowledge of how to use their competencies to give back to their community. And [we] are seeing the value in that so I hope that, that is you know, is setting down some roots in the community.' (Marie Belizaire, leadership programme manager, HigherEdOrg)

HigherEdOrg ESL Programme Manager Myrtho Izikyel discussed the ESL enrichment course. In her discussion, Myrtho alluded to the 'neo-colonial practices' mentioned earlier by HigherEdOrg Associate Director who believed that these practices kept Haitian nationals out of the job sector altogether. Myrtho explained the role of the ESL instructors:

'So, we are helping the students by giving them more tools to be more successful in whatever professions they have. Now after the 2010 earthquake, January 12, I think that English has become even more important in the sense now you've got all of these other international actors, NGOs and we don't necessarily want to be encouraging to work for NGOs, because it's not very sustainable. But at the same time, they need the tools to navigate those systems because of their work in the private sector. Most likely they are going to have some sort of interaction with these nongovernmental organizations.' (Myrtho Izikyel, ESL programme manager, HigherEdOrg)

Finally, 'financial support' as a sub-theme provides an opportunity to expand the Good Career Guidance framework. For instance, all of the HigherEdOrg participants discussed the benefits to not only the student but also their entire family when they were awarded a HigherEdOrg scholarship. The scholarship eliminates barriers to university access, which provides a pathway to decent work, or a suitable career postgraduation and an overall improved quality of life in the country. Two alumni described what it meant for them to earn a full university scholarship from HigherEdOrg. Ernest conveyed:

'[I]t was a big relief, it was definitely, it was because I often said, I have my brother that finished one year before me, but he did not succeed to go into the public college, so he spent one year doing nothing.' (Ernest Duncan, alumnus, HigherEdOrg)

Ernest's reflections speak about the lack of opportunity discussed earlier by HigherEdOrg student Olivia Jean, who conveyed it as an internal brain drain. Margreth Mathieu also discussed the benefits of the full scholarship offered to accepted students. She said:

' $[A]$ lot of the students are coming from lower low-income, rural backgrounds where they would, you know, not first of all have the financial means to pay the tuition [fee] at a lot of these universities.' (Margreth Mathieu, student recruiter/alumnus, HigherEdOrg)

Both alumni underscored the economic challenges experienced by post-secondary students in Haiti. They also conveyed the difficulty of attending university without bursaries or other forms of financial aid made available to prospective students. Given the extent of unemployment in Haiti, and the low average salary of the population, the scholarship provided by HigherEdOrg is undeniably invaluable for the percentage of overall university students who are accepted to the programme. Additionally, as all prospective HigherEdOrg students must demonstrate their financial need in order to receive the full scholarship to attend a university in Haiti, the funding awarded is a step prior to them achieving Benchmark 6 'encounters with further and higher education' (Holman, 2014). In this regard, 'financial support' as a sub-theme extends Holman's good career guidance when applied to low-income contexts like Haiti. More specifically, this theme highlights the necessity of coupling financial aid with university acceptance in order for Benchmark 6 to be achieved.

Despite the extent and nature of university and career challenges described by case study participants, those participants affiliated with HigherEdOrg believed that the comprehensive range of support and interventions offered by the organisation worked to alleviate the difficulties surrounding higher education and career expectations. The full scholarship and all it entailed helped to mitigate issues related to university access and persistence. The career and alumni services helped participants to develop skills required for the job market. The enrichment courses deepened student competencies and fostered their career development for the local job market.

\section{Discussion}

This study examined the higher education and career development experiences of emerging adults in Haiti, who in the context of this study are university students and graduates. The analysis of the data collected highlighted the challenges experienced by this group, and the strategies provided by HigherEdOrg to mitigate those career-related challenges. Findings from the analysis conducted revealed two overarching themes: challenges to a university-to-career pipeline in Haiti and multi-pronged career guidance. They are discussed below as they relate to previous research.

The study participants affiliated with HigherEdOrg explained the challenges experienced by university students in Haiti and the related implications on their future career outcomes. All participants discussed Haiti in the context of its economic realities. With respect to higher education matriculation, the lack of a financial aid system was a significant barrier for most university students, given the high rates of poverty in the country (CIA, 2019; Ferguson et al., 2014). As such, the full tuition scholarship offered by HigherEdOrg was critical. The financial environment discussed by participants is consistent with the economic inequality that emerging adults experience in developing countries (Juarez \& Gayet, 2014). Brain drain was also a topic of conversation for participants, and particularly the administrators reflected on that aspect. However, one participant, a university student Olivia Jean, offered a nuanced understanding of the issue. As noted in the findings, Olivia explained that despite pursuing and earning a university degree, a student often 'makes a way but his brain is not utilised, that means that he is not being utilised the way that he 
should.' This experience, of one's intellect being underutilised in their home country because of local job market realities, was conceptualised as an internal brain drain in previous research on emerging adolescent and adult experiences in Haiti (Vital, 2015, 2017; Ferguson et al., 2014). The 'mismatch in skills demands and supply' was also articulated by Tan et al. (2013, p. iii). Finally, the findings related to challenges indicated that the academic structure of universities in Haiti made it difficult for students to graduate, which in turn impacted their ability to pursue a career related to their disciplinary background. As a result, university students miss out on the positive outcomes of degree attainment: better jobs, including increased wages; opportunities for promotion; and social mobility (Brennan \& Teichler, 2008; Coates \& Edwards, 2011; Tight, 1989; UNESCO, 2009).

Research participants also discussed the career service strategies of HigherEdOrg: they found the comprehensive support useful to their career preparation and career trajectory. HigherEdOrg's multi-pronged approach to career guidance and training is consistent with research on the topic (Watts \& Fretwell, 2004). In particular, when reviewing the literature on career counselling at higher education institutions in developing country contexts, HigherEdOrg's strategies are similar to the effective practices discussed in empirical research (Bittaye et al., 2012; Maree, 2009; Sidiropoulou-Dimakakou et al., 2016; Sun \& Yuen, 2012). Holman's (2014) Good Career Guidance offered a useful framework for examining the components of the career services department at HigherEdOrg and how it fostered the career development of university students. Holman indicated that institutions must have a stable career programme, which presently exists at HigherEdOrg despite it not being a higher education institution, specifically. Career counselling must include personal guidance that addresses the needs of each pupil. This occurs as each student and programme alumni has access to the Alumni and Career Services Manager, who offers tailored individual and group support that mirrors the approach noted by Watts and Fretwell (2004). The Good Career Guidance framework emphasises linking curriculum learning to careers, and encounters with further and higher education. This is most evidenced by the three enrichment courses by HigherEdOrg. Students are enrolled in programme courses focused on leadership, information technology and English, while being full-time students at their respective universities. These enrichment courses provide opportunities for life-long learning (Chamorro-Premuzic \& Frankiewicz, 2019), and ensure that they are prepared to work in professional settings with the skills necessary for quality job performance (Birdsall, 1996; Maree, 2009; Iakovleva et al., 2011). The Holman framework also captures the experiential learning that is necessary for career training (Sidiropoulou-Dimakakou et al., 2016), specifically learning from career and labour market, encounters with employers, and employees and experiences of workplaces. As noted by the study participants, all HigherEdOrg students participate in internships as a function of the programme, while others have received opportunities for international engagement at various institutions in the
United States of America. Additionally, company representatives from internship locations as well as alumni working in their respective fields have served as guest speakers during the various workshops provided to students.

\section{Limitations of the study}

As is consistent with empirical research studies, this study has also limitations (Maxwell, 2005). Firstly, the study was conducted during the busiest month of the year for HigherEdOrg. The staff members were rewriting organisational handbooks, preparing for the close of the academic year, planning the HigherEdOrg graduation in a period of staff transition, nearing the end of their recruitment season, and preparing for the start of their new student orientation. It was also a busy time for students attending the state university who were in the middle of their examination period. Because of the ongoing staff and student commitments, it was difficult at times to schedule interviews and the length of many interviews was shortened because of participants' multiple competing priorities. The lack of access to higher education officials in Haiti was also a limitation. Another limitation of the study was language as most of the participants spoke limited to no English. I am not fluent in French, and I am a heritage speaker of Kreyòl Ayisyen [Haitian Creole]. Finally, the work reflected in this article was drawn from a larger case study on the Haitian higher education system, which was not explicitly focused on career counselling and guidance of university students in Haiti. As such, the findings related to this particular topic were limited. Despite these limitations, this study contains rich data on the experiences of study participants within the higher education environment in Haiti. It offers insightful perspectives on higher education and career development experiences of emerging adults in a developing country context. Furthermore, it highlights strategies that have proven successful and can be drawn from in the design of interventions in contexts similar to that of Haiti.

\section{Implications and recommendations}

Implications from this study re-imagine higher education and career development in country contexts like Haiti. The findings highlighted the internal brain drain that occurs in Haiti such that highly educated individuals have diminished opportunities to enter the local workforce. An implication of this research is the possibility of a new model of higher education for Haiti's particular context that integrates career counselling as a new area of focus. As noted by the scholarship on workforce development in developing countries, many qualified individuals are not able to secure positions that are aligned with their skills and academic training. Yet, HigherEdOrg serves as a model that both prepares university students for the job market and trains them with the soft skills that employers seek along with appropriate academic preparation. This understanding occurs through the partnerships developed by HigherEdOrg with local companies and international organisations. Other NGOs and 
disciplinary departments at higher education institutions can model their approach in similar ways.

This research also reveals implications for the provision of career guidance in higher education institutions that occurs at the start of the student's university tenure and is embedded throughout their matriculation. This approach would be counter to the experiences of students who begin their search to secure jobs after graduation and are nearing the conclusion of their university career. While this timeline may work for university students in countries that have stronger economies, the HigherEdOrg model suggests that this timeline may prove too late for students in countries like Haiti.

An implication for theory addresses the eight benchmarks embedded in Holman's (2014) Good Career Guidance. Benchmark 6 emphasises the necessity of increased education and the pursuit of higher education in particular. Yet, less than $1 \%$ of the Haitian population attends university, and tuition costs make this endeavour infeasible for most of them. The subtheme of 'financial support' as reflected in the findings underscores the critical need to couple funding with the university pursuits that Holman indicates as a function of good career guidance. As such, theories, or frameworks as reflected in Holman's work, must be flexible enough to adapt to lower-resourced country contexts like Haiti.

Finally, a significant implication of this research is the need for partnerships between the higher education sector, the higher education-centred NGOs and the Ministry of Education. Such a coalition would reveal the perceptions of corruption in the local workforce, as highlighted by the study participants, and will provide opportunities for coordinated interventions. Additionally, it will diminish the duplication of efforts in response to local, country-wide and global events; for instance, the increased unavailability of jobs in developing countries as a result of the COVID-19 pandemic. The extent of the economic fallout that will occur in Haiti as a result, or in a similar context, is still unknown.

Recommendations for practice are challenging for countries that are resource constrained like Haiti. However, they are worth mentioning and include the adoption of career guidance in higher education institutions, and as a function of the services provided to university students by the many NGOs that exist in Haiti. Although there are contextual data on the range of vocational and technical education and training that exist in Haiti, there does not seem to be a clear understanding of any career counselling specific to university students that exists, or any empirical research that has examined this topic previously. Recommendations for policy include the Ministry of Education providing basic guidelines or standards for universities and stakeholders to follow as a way for career development to emerge as a service provided to students in the Haitian higher education system. Recommendations for future research include an environmental scan of the career guidance that is offered to university students in Haiti. This scan will reveal what is and what is not occurring in the higher education environment, and will inform the design of targeted and relevant research projects. Additionally, more stakeholders should be interviewed to determine a holistic and multi-pronged strategy between key stakeholders to address the career counselling and development challenges experienced by university students and graduates in Haiti.

Recommendations for theory include an expansion of the Good Career Guidance framework to incorporate the social and economic realities of developing countries like Haiti, particularly as the career development approach may not resemble the process of countries reflected in Holman's (2014) research.

\section{Conclusion}

Overall, emerging adults in Haiti experience considerable challenges in both their higher education experiences and career development. However, the findings of this study revealed that there is a pipeline between higher education attainment and positive career outcomes for those university students affiliated with HigherEdOrg. More specifically, the academic advisories and support offered by the organisation, coupled with career counselling and guidance, resulted in an $80 \%$ graduation rate as compared to $40 \%$ for the entire country population, which in turn led to a $90 \%$ employment rate for HigherEdOrg alumni, as compared to $50 \%$ for the rest of the country. These statistics are relevant. Although career counselling and guidance might be customary for university students in many countries, it is unique to Haiti and not readily accessible to the emerging adults there. Thus, HigherEdOrg serves as an innovative presence in Haiti, and a model for other countries in similar contexts.

\section{Acknowledgements Competing interests}

The author declare that they have no financial or personal relationships that may have inappropriately influenced them in writing this article.

\section{Author's contributions}

L.M.V. is the sole author of this research article.

\section{Funding information}

No funding was provided for the development of this manuscript. Funding was provided by Michigan State University for data collection.

\section{Data availability}

The data that support the findings of this study are available from the corresponding author, L.M.V., upon reasonable request. 


\section{Disclaimer}

The views and opinions expressed in this article are those of the author and do not necessarily reflect the official policy or position of the institution or funder.

\section{References}

Akinyemi, S., \& Ofem, I.B. (2012). Planning and funding of higher education in Nigeria: The challenges. International Education Studies, 5(4), 86-95. https://doi.org/ $10.5539 /$ ies.v5n4p86

Arnett, J.J. (1998). Learning to stand alone: The contemporary American transition to adulthood in cultural and historical context. Human Development, 41, 295-315. adulthood in cultural and historical
https://doi.org/10.1159/000022591

Arnett, J.J. (2000). Emerging adulthood: A theory of development from the late teens through the twenties. American Psychologist, 55(5), 469-480. https://doi.org/ through the twenties. American
$10.1037 / 0003-066$ X.55.5.469

Bigelow, J.K. (2010). Establishing a training programme for rehabilitation aides in Haiti: Successes, challenges, and dilemmas. Disability and Rehabilitation, 32(8), 656-663. https://doi.org/10.3109/09638280903204682

Birdsall, N. (1996). Public spending on higher education in developing countries: Too much or too little? Economics of Education Review, 15(4), 407-419. https://doi. org/10.1016/S0272-7757(96)00028-3

Bittaye, M., Odukogbe, A.T.A., Nyan, O., Jallow, B., \& Omigbodun, A.O. (2012) Medical students' choices of specialty in The Gambia: The need for caree counselling. BMCMedical Education, 12(1), 72-81. https://doi.org/10.1186/1472 6920-12-72

Belyakov, A., Cremonini, L., Mfusi, M., \& Rippner, J. (2009). The effects of transitions on access to higher education. Washington, DC: Institute for Higher Education Policy.

Brennan, J., \& Naidoo, R. (2008). Higher education and the achievement (and/or prevention) of equity and social justice. Higher Education, 56(3), 287-302. https:// doi.org/10.1007/s10734-008-9127-3

Brennan, J., \& Teichler, U. (2008). The future of higher education and of higher education research: Higher education looking forward: An introduction. Higher education research: Higher education looking forward: An introduction.

Brice, M., \& Marsh, S. (2016). Hurricane Matthew hammers Haiti and Cuba, bears down on U.S. Reuters. Retrieved from https://www.reuters.com/article/us-stormmatthew/hurricane-matthew-hammers-haiti-and-cuba-bears-down-on-u-sidUSKCN1240BH

Carlson, W., Désir, A., Goetz, S., Hong, S., Jones, S., \& White, J. (2011). The Haitian diaspora \& education reform in Haiti: Challenges \& recommendations. New York, NY: Columbia University Schools of International and Public Affairs.

Central Intelligence Agency [CIA]. (2019). Haiti: CIA World Fact Book. Retrieved from https://www.cia.gov/library/publications/the-world-factbook/

Chamorro-Premuzic, T., \& Frankiewicz, B. (2019). Does higher education still prepare people for jobs? Harvard Business Review. Retrieved from https://hbr.org/ 2019/01/does-higher-education-still-prepare-people-for-jobs

Cho, J., \& Trent, A. (2006). Validity in qualitative research revisited. Qualitative research, 6(3), 319-340. https://doi.org/10.1177/1468794106065006

Clinton, H. (2012). Remarks with Haitian Prime Minister Laurent Lamothe after their meeting. US Department of State. Retrieved from http://www.state.gov/ mecting. US /rm/2012/07/195413.htm

Coates, H., \& Edwards, D. (2011). The graduate pathways survey: New insights on education and employment outcomes five years after bachelor degree completion. Higher Education Quarterly, 65(1), 74-93. https://doi.org/10.1111/ j.1468-2273.2010.00471.x

Creswell, J.W. (2009). Research design: Qualitative, quantitative, and mixed methods approaches (3rd edn.). Thousand Oaks, CA: Sage.

Dumay, H.E. (2009). The paradox of high satisfaction and low choice: A study of student satisfaction and university access in Haiti (Publications no. 3359047). Doctoral dissertation. Chestnut Hill, MA: Boston College. ProQuest Dissertations Publishing.

Dumay, H. (2010). Can haitian higher education rise from the rubble? International Higher Education, 59, 2-3.

Central Intelligence Agency. (2021). Haiti: Economic overview. The World Factbook. Retrieved February 16, 2021 from https://www.cia.gov/the-world-factbook/ countries/haiti/\#economy

Endicott, L. (2019). Innovation in higher education: Three sites in Haiti (Publications no. 27667646). Doctoral dissertation. El Paso, TX: University of Texas at El Paso. no. 27667646). Doctoral dissertation.
ProQuest Dissertations Publishing.

Ferguson, G. M., Desir, C., \& Bornstein, M.H. (2014). 'Ayiti Cheri' cultural orientation of early adolescents in rural Haiti. The Journal of Early Adolescence, 34(5), 621-637. https://doi.org/10.1177/0272431613503214

Flyvbjerg, B. (2006). Five misunderstandings about case-study research. Qualitative Inquiry, 12(2), 219-245.

Glesne, C. (2011). Becoming qualitative researchers: An introduction (4th edn.) Boston, MA: Pearson.

Grandy, G. (2010). Instrumental case study. In J. Mills, G. Durepos, \& E. Wiebe (Eds.), Encyclopedia of case study research (pp. 474-475). Newbury Park, CA: SAGE Publications, Inc. https://www.doi.org/10.4135/9781412957397.n175
Haitian Education and Leadership Program (HELP), (n.d.). How HELP is changing the stats. Retrieved from https://uhelp.net/our-story/results/

Harper, S.R., Patton, L.D., \& Wooden, O.S. (2009). Access and equity for African American students in higher education: A critical race historical analysis of policy efforts. The Journal of Higher Education, 80(4), 389-414. https://doi.org/10.1080/ 00221546.2009 .11779022

Holman, J. (2014). Good career guidance. London: Gatsby Trust.

Hoyt, J.E., \& Allred, E. (2008). Educational and employment outcomes of a degree completion program. The Journal of Continuing Higher Education, 56(2), 26-33. https://doi.org/10.1080/07377366.2008.10400150

lakovleva, T., Kolvereid, L., \& Stephan, U. (2011). Entrepreneurial intentions in developing and developed countries. Education + Training, 53(5), 353-370.

Index Mundi. (2019). Haiti labour force by occupation. Retrieved from https://www. indexmundi.com/haiti/labor_force_by_occupation.html

Interuniversity Institute for Research and Development [INURED]. (n.d.). The challenge for Haitian higher education: A post-earthquake assessment of higher education institutions in the Port-au-Prince metropolitan area. Retrieved from http://www.inured.org/reports.html

Jacob, S. (2020). Massification and the public financing of higher education in Hait: Issues and challenges. International Review of Administrative Sciences, 86(2), 349-367. https://doi.org/10.1177/0020852318781457

Jadotte, E. (2012). Brain drain, brain circulation and diaspora networks in Haiti. In Least developed countries report 2012: Harnessing remittances and diaspora knowledge to build productive capacities (pp. 1-44). Geneva, Switerzland: United Nations Conference on Trade and Development.

Janjua, S., \& Naveed, A. (2009). Skill acquisition and the significance of informal training system in Pakistan-some policy implications (RECOUP Policy Brief, 7 , pp. 1-5). Cambridge: University of Cambridge, Faculty of Education, Research pp. 1-5). Cambridge: University of Cambridge, Facul
Consortium on Educational Outcomes and Poverty.

Joseph, W. (2011). The effects of brain drain on Haiti. College Park, MD: University of Maryland.

Juarez, F., \& Gayet, C. (2014). Transitions to adulthood in developing countries. Annual Review of Sociology, 40(1), 521-538. https://doi.org/10.1146/annurev-soc052914-085540

Kezar, A.J., Chambers, T.C., \& Burkhardt, J.C. (Eds.). (2005). Higher education for the public good: Emerging voices from a national movement. San Francisco, CA: Jossey-Bass.

King, K., \& Palmer, R. (2010). Planning for technical and vocational skills development. Paris: UNESCO, International Institute for Educational Planning.

Lemay-Hébert, N., Marcelin, L.H., Pallage, S., \& Cela, T. (2020). The internal brain drain: Foreign aid, hiring practices, and international migration. Disasters, 44(4), 621-640. https://doi.org/10.1111/disa.12382

Lewis, D.R., \& Hearn, J. (Eds.). (2003). The public research university: Serving the public good in new times. Lanham, MD: University Press of America.

Lowell, L.B., \& Findlay, A.M. (2001). Migration of highly skilled persons from developing countries: Impact and policy responses - Synthesis report. International Migration Papers No. 44. Geneva: International Labour Office.

Maree, J.G. (2009). Career counselling in the 21st century: South African institutions of higher education at the crossroads. South African Journal of Higher Education, 23(3), 436-458. https://doi.org/10.4314/sajhe.v23i3.51017

Maxwell, J.A. (2005). Qualitative research design: An interactive approach: An interactive approach (2nd edn.). Thousand Oaks, CA: Sage.

McKechnie, L.E. (2008). Participant observation. In L.M. Given (Ed.), The SAGE encyclopedia of qualitative research methods (pp. 599-600). Los Angeles, CA: SAGE Publications.

Miles, M.B., Huberman, A.M., \& Saldaña, J. (2014). Qualitative data analysis: A methods sourcebook (3rd edn.). Thousand Oaks, CA: Sage.

Ozsoy, C. (2008). The contribution of higher education to economic development. In Proceedings of the 8th global conference on business and economics (pp. 18-19). Florence, Italy: s.n.

Patton, M. (2002). Qualitative research and evaluation methods (3rd edn.). Thousand Oaks, CA: Sage.

Pierre, A., Arrellano, M.E.C., Ramírez, L.V., Gómez, G.M., \& Romero, O.H. (2014) Higher education in agriculture and sustainable development in Haiti. International Journal of Social Sciences and Entrepreneurship, 1(2), 36-53.

Rameau, P., Louime, C., \& Behar-Horenstein, L. (2007). A plan for the creation of a community college system in developing countries: Case study Haiti. European Journal of Social Sciences, 5(2), 104-120.

Ratha, D., \& Shaw, W. (2007). South-South migration and remittances (No. 102). Washington, DC: World Bank Publications.

RTI International. (2018). Vocational students in Haiti learn skills to power new careers and the country's economy. Retrieved from https://www.rti.org/news/vocationalstudents-haiti-learn-skills-power-new-careers-and-country\%E2\%80\%99seconomy

Sidiropoulou-Dimakakou, D., Argyropoulou, K., Drosos, N., Kaliris, A., \& Mikedaki, K. (2016). Exploring career management skills in higher education: Perceived selfefficacy in career, career adaptability and career resilience in Greek university students. International Journal of Learning, Teaching and Educational Research, 14(2), 36-52.

Smith, L.T. (1999). Decolonizing methodologies: Research and indigenous peoples. London: Zed Books. 
Somers, P., Haines, K., Keene, B., Bauer, J., Pfeiffer, M., McCluskey, J., ... Sparks, B. (2006). Towards a theory of choice for community college students. Community College Journal of Research and Practice, 30(1), 53-67. https://doi.org/10.1080/ 10668920500248886

Stake, R.E. (2005). Qualitative case studies. In N.K. Denxin \& Y.S. Lincoln (Eds.), The SAGE handbook of qualitative research (pp. 443-446). Thousand Oaks, CA: SAGE.

Sun, V.J., \& Yuen, M. (2012). Career guidance and counselling for university students in China. International Journal for the Advancement of Counselling, 34(3) 202-210. https://doi.org/10.1007/s10447-012-9151-y

Suzuta, E. (2011, September 28-29). Education in Haiti: An overview of trends, issues, and plans. Proceeding of the 3rd World Innovative Summit for Education, Port-au Prince, 28-29 September 2011. Port-au Prince, Haiti: s.n.

Tan, J.P., Lee, K.H., Valerio, A., \& Nam, J.Y.J. (2013). What matters in workforce development: A framework and tool for analysis. Washington, DC: World Bank.

The World Bank. (2020). Indicators. Retrieved from https://data.worldbank.org/ indicator/

Tight, M. (1989). The ideology of higher education. In O. Fulton (Ed.), Access and institutional change (pp. 85-98). Bristol, PA: Taylor \& Francis.

United Nations. (2015). Sustainable development goal 8: Decent work and economic growth. Retrieved from https://unstats.un.org/sdgs/report/2020/ goal-08/
United Nations Educational Scientific Cultural Organization (UNESCO). (2009). World conference on higher education: The new dynamics of higher education and research for societal change and developments. Retrieved from https://unesdoc. unesco.org/ark:/48223/pfo000183277

United Nations Educational Scientific Cultural Organization (UNESCO). (2014). Position paper on education post-2015. Retrieved from http://www.unesco.org/new/ fileadmin/MULTIMEDIA/HQ/ED/ED new/UNESCOPositionPaperOnEDpost-2015.pdf

United States Agency for International Development (USAID). (2017). Haiti-education. Retrieved from https://2012-2017.usaid.gov/haiti/education

Vital, L.M. (2015). Tet chage! An investigation of the Haitian education and leadership program in the higher education landscape in Haiti. Doctoral dissertation. East Lansing, MI: Michigan State University.

Vital, L.M. (2017). Looking ahead post disaster: What Latin American and Caribbean higher education can learn from Haiti. Revista de Educación Superior en América Latina, 3, 3-5.

Watts, A.G., \& Fretwell, D.H. (2004). Public policies for career development. Case studies and emerging issues for designing career information and guidance systems in developing and transition economies. Washington, DC: The World Bank Education Advisory Service.

Yin, R.K. (2003). Case study research: Design and methods (Vol. 5). Thousand Oaks, CA: SAGE Publications.

Zanotti, L., Stephenson, M., \& McGehee, N. (2016). International aid, local ownership and survival: Development and higher education in rural Haiti. VOLUNTAS: International Journal of Voluntary and Nonprofit Organizations, 27(1), 273-298. https://doi.org/10.1007/s11266-015-9618-7 